ISSN 1392-3196 / e-ISSN 2335-8947

Zemdirbyste-Agriculture, vol. 105, No. 3 (2018), p. 221-226

DOI $10.13080 / \mathrm{z}-\mathrm{a} .2018 .105 .028$

\title{
Changes in weed seed bank and flora as affected by soil tillage systems
}

\author{
Ona AUŠKALNIENĖ, Gražina KADŽIENĖ, Daiva JANUŠAUSKAITĖ, Skaidrė SUPRONIENĖ \\ Institute of Agriculture, Lithuanian Research Centre for Agriculture and Forestry \\ Instituto 1, Akademija, Kedainiai distr., Lithuania \\ E-mail: ona.auskalniene@lammc.lt
}

\begin{abstract}
Tillage not only changes soil properties but also serves as a weed control means. Different soil tillage systems were investigated in a long-term field experiment conducted during 2003-2012 at Institute of Agriculture, Lithuanian Research Centre for Agriculture and Forestry. The experiment was carried out in a cereal-based crop rotation. The experimental design included the following tillage treatments: 1) conventional tillage (CT): mouldboard ploughing at 22-24 cm depth; 2) minimum tillage (MT): stubble cultivation at 10-12 cm depth, non-selective herbicide (glyphosate) spray applied after harvesting; 3) no tillage (NT): direct drilling, non-selective herbicide spray applied after harvesting. This paper presents the data from the 2007-2012 experimental period. To determine weed seed bank, soil samples were taken in 2007 after spring barley harvesting and in 2012 after winter oilseed rape harvesting. Samples of weeds for the determination of fresh and dry mass were collected in 2011 and 2012 in winter wheat and winter oilseed rape crops during the growing period.

The weed seed bank in the soil significantly decreased over the five-year period. However, significantly the highest number of seeds in the soil was found in the no tillage plots. Significant differences in the weed species composition between the different tillage systems were recorded: no tillage system promoted infestation of some broadleaf weeds, particularly Capsella bursa-pastoris. The lowest weed mass was determined for the conventional tillage plots, compared to minimum tillage, and especially no tillage plots.
\end{abstract}

Key words: soil, species composition, tillage, weeds, weed mass, weed seed bank.

\section{Introduction}

Weeds are a major problem in most cropping systems, and their control is essential for successful crop production. The goal of weed control is not only to prevent crop yield loss, but also to minimize weed seed reserves in the soil, because the soil seed bank is the primary source of new infestations of annual weeds and represents the majority of the weed species composition. The majority of seeds entering the seed bank come from annual weeds growing in the fields. The size of the seed bank reflects past and present field management (Auffret, Cousins, 2011). Weed seed bank analysis provides knowledge on the effect of agricultural management practices on weed community dynamics. Such knowledge is difficult to acquire from short-term studies based on actual weed flora, whose composition is subjected to considerable variation in time and space (Birthisel et al., 2015). Weed communities are also affected by crop type and sequence. Agricultural crops with different growth cycles (winter or spring) affect weed spread, germination and growth (Andrade et al., 2017).

Tillage is an important aspect of farm management. Non-inversion or minimum tillage reduces energy usage, enables faster soil preparation and improves soil aggregation (Vakali et al., 2011; Bottineli et al., 2017), but deep-tillage implements that invert soil layers, bury weed seeds deep enough to prevent their germination and emergence (Farmer et al., 2017). In some cases, integrated use of mouldboard plough reduced the emergence of weeds by at least $95 \%$ over two growing seasons (Bagavathiannan, Norsworthy, 2012).

The magnitude of the effects of management practices on soil properties have been reported in the numerous studies (Feiza et al., 2011; Velykis et al., 2014; Munkholm et al., 2016; Nugis et al., 2016). However, changes in agricultural management practices encourage changes in weed seed bank characteristics, which often lead to the changes in the size and species composition of the weed flora (Nichols et al., 2015). Species composition of the flora may be more important than the total number of seeds (Jastrzębska et al., 2013).

Nevertheless, results of some investigations showed a close relationship between the emerged weed plants at the soil surface and the seedbank in the following year (Sjursen et al., 2008).

Please use the following format when citing the article:

Auškalnienė O., Kadžienė G., Janušauskaitė D., Supronienė S. 2018. Changes in weed seed bank and flora as affected by soil tillage systems. Zemdirbyste-Agriculture, 105 (3): 221-226 DOI 10.13080/z-a.2018.105.028 
The weed seed bank develops in two ways: it increases in amount from those weed seeds that mature weed plants spread by wind and running water into soil, and decreases by that amount which germinates or is lost due to activity of soil fauna. The number of weed seeds increased at sites with a low crop cover and a high density of weed plants at the soil surface. For example, winter cereals, sunflowers and lupines increased the weed seed bank by $30-40 \%$. Grass-clover mixtures, however, reduced the seedbank by $39 \%$ (Albrecht, 2005). Analysis of the size and composition of the weed seedbank in the soil can provide information on the past and present weed populations and forecast any future weed problems (Auffret, Cousins, 2011). Changes in the soil weed seed reserves depend on soil tillage, crop rotation, and weed control (Auškalnienè, Auškalnis, 2009; Skuodienè et al., 2013). Weed community composition in the surface $(0-15 \mathrm{~cm})$ layer seems more influenced by tillage system than by crop rotation (Barberi, Lo Cascio, 2001). Researchers have been interested in the use of weed management control strategies aimed at the reduction of the soil weed seedbank to prevent large above ground weed communities and reduce weed management costs (Nichols et al., 2015). Some studies showed that the weed population emergence after cultivation was related to the size and composition of the weed seed bank (Hossain, Begum, 2015), nonetheless in other studies the relationship was found between weed seed bank and aboveground communities only for a small number of weed species (Gomaa, 2016). Albrecht (2005) found that the number of weed seeds increased at sites with low crop cover and high density of weed plants at the soil surface. Earlier harvesting of spring barley at the milky stage of maturity essentially decreased the reserves of the soil seed bank (Pilipavičius, 2013).

The interest in reduced soil tillage in Lithuania has increased over the last ten years. It was established that shallow ploughing and rototilling did not exert any negative effect on soil agrochemical and physical properties and grain mycoflora (Feiza et al., 2011; Suproniene et al., 2011), nonetheless abandonment of soil ploughing and use of shallow loosening by a rotary cultivator, compared with deep ploughing, resulted in an increase in weed incidence (Juchnevičienè et al., 2012).

The influence of tillage system on soil weed seed bank was investigated at the Institute of Agriculture in Lithuania. Previous studies showed that the highest number of weed seed species was found in the treatments with reduced and no tillage in the top soil layer $(0-5 \mathrm{~cm})$, in deeper soil layers no differences in species number of weed seeds were found (Auškalnienè, Auškalnis, 2009). Integration of preventive weed control measures with curative approaches should reduce weed management costs and the realization of its benefits for food security (Rao et al., 2017). Knowledge of associations between weed seed bank and management practices is an essential step towards development of alternative weed management strategies (Lal et al., 2016).

The aim of the present study was to evaluate the influence of different soil tillage intensities on the soil weed seed bank and weed flora.

\section{Materials and methods}

Long-term field experiments were conducted during 2003-2012 at the Institute of Agriculture, Lithuanian Research Centre for Agriculture and Forestry, in Dotnuva $\left(55^{\circ} 23^{\prime} 50^{\prime \prime} \mathrm{N}\right.$ and $\left.23^{\circ} 51^{\prime} 40^{\prime \prime} \mathrm{E}\right)$, Central
Lithuania. The sequence of crops rotation was as follows: winter wheat (2003-2004, 2007-2008, 2010-2011), winter oilseed rape (2011-2012), spring wheat (2005), spring barley $(2006,2009)$ and field pea $(2007,2010)$. The soil was prepared according to the experimental design: 1) stubble cultivation to $10-12 \mathrm{~cm}$ depth, ploughing to $22-24 \mathrm{~cm}$ depth, tillage with a precision seedbed cultivator before sowing to $4-5 \mathrm{~cm}$ depth, sowing with a disc coulter drill - conventional tillage (CT); 2) stubble cultivation to $10-12 \mathrm{~cm}$ depth, sowing with a disc sowing aggregate non-selective herbicide (glyphosate) spray applied after harvesting - minimum tillage (MT); 3) direct drilling; non-selective herbicide (glyphosate) spray applied after harvesting - no tillage (NT). This paper presents the data from the 2007-2012 experimental period.

The field experiment was arranged as block design in four replicates. Gross plot size was $10 \times 20$ $\mathrm{m}$ and net harvested plot size $2.3 \times 10 \mathrm{~m}$. According to WRB (2014), the soil is classified as an EndocalcariEpigleyic Cambisol (CM-g.lp-can), of a loam texture (Table 1).

Table 1. Physico-chemical properties of the experimental site (Dotnuva, Kèdainiai distr.)

\begin{tabular}{lccc}
\hline \multirow{2}{*}{ Soil characteristics } & \multicolumn{3}{c}{ Depth } \\
\cline { 2 - 4 } & $0-10 \mathrm{~cm}$ & $10-20 \mathrm{~cm}$ & $20-30 \mathrm{~cm}$ \\
\hline Texture & loam & loam & loam \\
$\mathrm{pH}$ & 7.0 & 7.0 & 6.9 \\
$\mathrm{P}_{2} \mathrm{O}_{5} \mathrm{mg} \mathrm{kg}^{-1}$ & 256 & 201 & 206 \\
$\mathrm{~K}_{2} \mathrm{O} \mathrm{mg} \mathrm{kg}^{-1}$ & 272 & 228 & 216 \\
Total N g kg$^{-1}$ & 1.52 & 1.46 & 1.39 \\
Humus g kg-1 & 22.1 & 21.1 & 20.1 \\
Field capacity m $\mathrm{m}^{-3}$ & 0.31 & 0.30 & 0.28 \\
\hline
\end{tabular}

To determine soil weed seed bank, soil samples were taken in 2007 and 2012 after the harvesting of spring barley (2007) and winter oilseed rape (2012). Two soil cores from 0-10 cm depth were randomly taken from each plot, using a $5 \mathrm{~cm}$ diameter steel probe. The samples were stored at $4{ }^{\circ} \mathrm{C}$ in the dark until processing (Barberi, Lo Cascio, 2001). The soil samples were placed into sieves (screen size $0.25 \mathrm{~mm}$ ) and soaked in water for 10 minutes to soften. After soaking, the soil was placed under running tap water and hand manipulated to remove fine soil particles. After completion of soil washing, the remaining contents were dried on filter paper in glass Petri dishes. The dried samples were passed through sieves with a screen size ranging from 1.6 to $0.5 \mathrm{~mm}$. After sieving, the contents of each sieve were analysed. Weed seeds were counted and identified using binoculars with $8^{\times}$magnification. Seed viability was determined by "destructive crushing" using forceps (Rahman et al., 1995). The above ground number and mass of weeds were established twice: in 2011 and 2012 in mid-summer in winter wheat (2011) and winter oilseed rape (2012) crops. Weeds were hand-harvested using $0.25 \mathrm{~m}^{-2}$ random quadrats for each plot with four replications (Rial-Lovera et al., 2016).

The data were subjected to the analysis of variance (ANOVA) from package SELEKCIJA (Raudonius, 2017). To achieve the homogeneity of variance, the data were $(\log +2)$ transformed.

\section{Results and discussion}

It has been previously documented that longterm cultivation and different tillage systems produce important changes in the composition and density of soil seed banks (Cardina et al., 2002; Gulshan et al., 2013). 
In our study, the soil weed seed bank varied in density depending on the tillage system (Fig. 1).

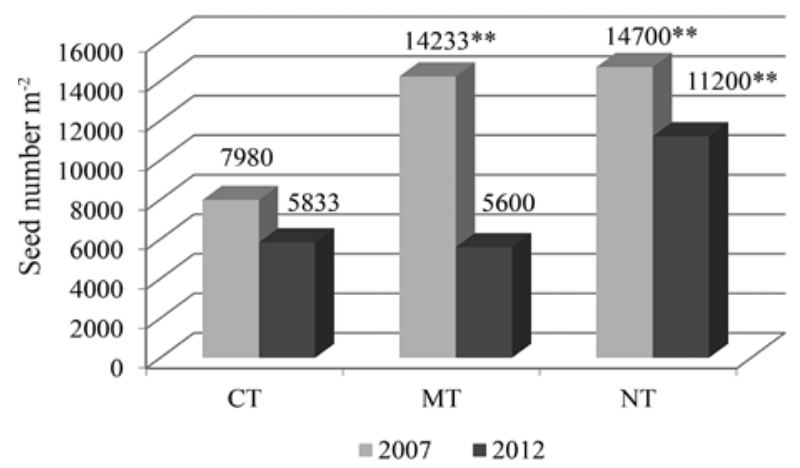

** - significant at $P<0.01$ between treatments; CT conventional tillage 20-22 cm depth, MT - minimum tillage $10-12 \mathrm{~cm}$ depth, NT - no tillage

Figure 1. Changes in the number of weed seeds in 0-10 $\mathrm{cm}$ soil layer as influenced by the different tillage systems (2007 and 2012)

As is seen from Figure 1, the highest number (14700) of weed seeds $\mathrm{m}^{-2}$ was extracted from the soil samples taken from the no tillage plots. Similar seed counts (14233) were found in the minimum tillage plots, while the seed counts in the conventional tillage plots were significantly lower (over a five-year period the soil weed seed bank significantly $(P>0.01)$ decreased). However, the differences between the tillage systems remained - in less disturbed soil there was a significantly higher weed seed number, compared to conventional tillage.
Sixteen weed species were found in the soil weed seed bank in the study area. The main weeds in weed seed bank were annual dicotyledonous: Chenopodium album, Stellaria media and Lamium purpureum, prevalent in 2007 (Fig. 2).

In 2007, weed species composition in all tillage systems was similar: C. album in all treatments composed $32.2-35.6 \%$, S. media $21.7-26.6 \%$, L. purpureum 19.3 $29.8 \%$ of the total weed count (Table 2 ).

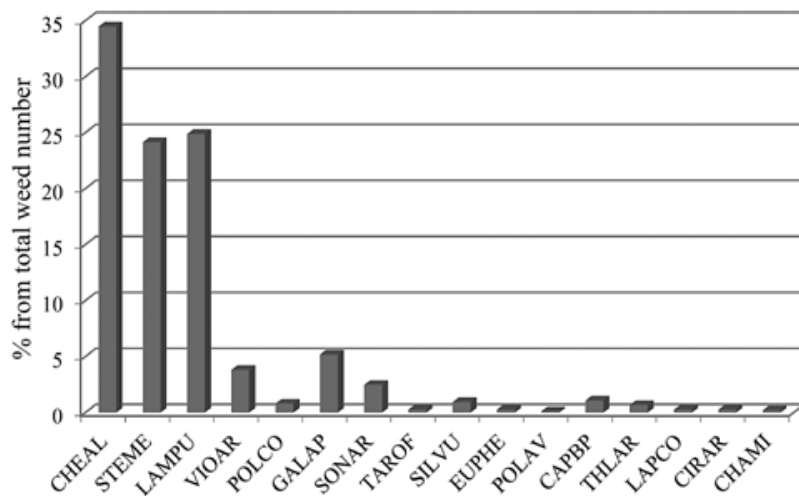

CHEAL - Chenopodium album, STEME - Stellaria media, LAMPU - Lamium purpureum, VIOAR - Viola arvensis, POLCO - Fallopia convolvulus, GALAP - Galium aparine, SONAR - Sonchus arvensis, TAROF - Taraxacum officinale, SILVU - Silenia vulgaris, EUPHE - Euphorbia helioscopia, POLAV - Polygonum aviculare, CAPBP - Capsella bursa-pastoris, THLAR - Thlaspi arvense, LAPCO - Lapsana communis, CIRAR - Circium arvense, CHAMI - Chaenorhinum minus

Figure 2. Weed species composition in the weed seed bank (in 2007)

Table 2. Weed seed species composition (\%) in 0-10 cm soil layer in different tillage systems (in 2007)

\begin{tabular}{|c|c|c|c|}
\hline \multirow{2}{*}{ Weed species } & \multicolumn{3}{|c|}{ Tillage system } \\
\hline & $\mathrm{CT}$ & MT & NT \\
\hline Chenopodium album L. & 35.6 & 32.2 & 35.6 \\
\hline Stellaria media (L.) Vill. & 24.1 & 21.7 & 26.6 \\
\hline Lamium purpureum L. & 25.5 & 29.8 & 19.3 \\
\hline Viola arvensis Murray & 3.9 & 3.8 & 3.7 \\
\hline Fallopia convolvulus (L.) À. Löve & 0.8 & 0.8 & 0.8 \\
\hline Galium aparine $\mathrm{L}$. & 5.0 & 5.8 & 4.7 \\
\hline Sonchus arvensis L. & 2.0 & 1.7 & 3.7 \\
\hline Taraxacum officinale F.H. Wigg & 0.6 & 0.0 & 0.2 \\
\hline Silenia vulgaris (Moench) Garcke & 0.3 & 1.9 & 0.6 \\
\hline Euphorbia helioscopia L. & 0.6 & 0.2 & 0.0 \\
\hline Polygonum aviculare L. & 0.3 & 0.0 & 0.0 \\
\hline Capsella bursa-pastoris (L.) Medik. & 0.6 & 0.2 & 2.4 \\
\hline Thlaspi arvense L. & 0.8 & 0.6 & 0.6 \\
\hline Veronica hederifolia L. & 0.0 & 0.0 & 0.0 \\
\hline Lapsana communis L. & 0.0 & 0.6 & 0.2 \\
\hline Cirsium arvense (L.) Scop. & 0.0 & 0.6 & 0.2 \\
\hline Chaenorhinum minus (L.) Lange & 0.0 & 0.2 & 0.4 \\
\hline
\end{tabular}

CT - conventional tillage 20-22 cm depth, MT - minimum tillage 10-12 cm depth, NT - no tillage

All other weeds composed $8-26.8 \%$ of the total weed count. Species composition in the weed seed banks changed during the five years' period. The number of weed species slightly decreased from sixteen to twelve. Some species disappeared and new species emerged, especially high incidence was recorded for Tripleurospermum inodorum and annual monocotyledonous weeds, particularly Echinochloa crus-galli (Fig. 3).

Changes in weed species composition occurred in all tillage systems - in the minimum tillage and no tillage plots a significant increase in $T$. inodorum and a decrease in C. album were recorded. E. crus-galli were found in all tillage systems, with particularly high incidence recorded in minimum tillage treatment $22 \%$ from the total weed number present in the sample (Table 3 ).

This is in line with the findings of Barberi and Lo Cascio (2001) suggesting that different soil tillage systems produce important changes in density of soil seed bank and this difference takes short time to become evident (Feldman et al., 1997). The results of our investigations, suggesting that systems causing less soil disturbance allow the build-up of larger soil seed bank, agree with those of Feldman et al. (1997). The highest density of weed seeds in the no tillage system, as compared to the conventional system, has been reported by Cardina et al. (2002) as well. According to Feldman et al. (1994), this 


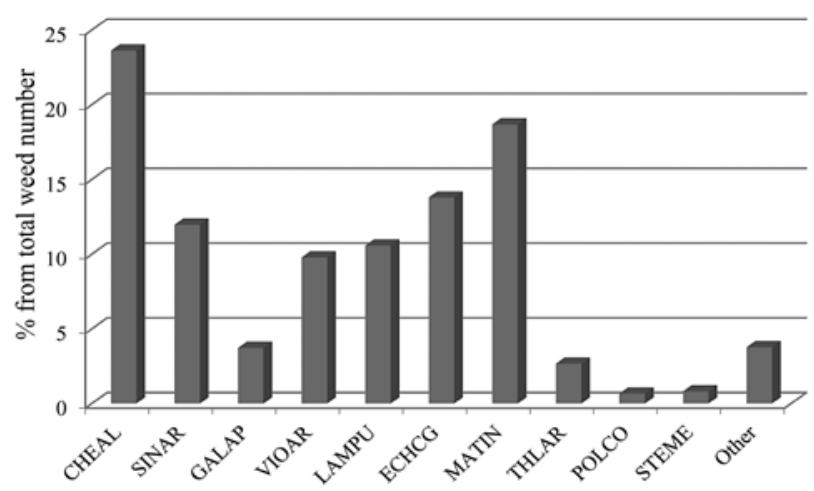

CHEAL - Chenopodium album, SINAR - Sinapis arvensis, GALAP - Galium aparine, VIOAR - Viola arvensis, LAMPU Lamium purpureum, ECHCG - Echinochloa crus-galli, MATIN - Tripleurospermum inodorum, THLAR - Thlaspi arvense, POLCO - Fallopia convolvulus, STEME - Stellaria media

Figure 3. Weed species composition in the weed seed bank (in 2012) can be accounted for by the two factors: accumulation of crop residues on the surface, therefore more protection from predation and less movement of seeds along the soil profile, therefore less dormancy-breaking mechanisms and lower exposure of seeds to potential hazards. According to Ali et al. (2017), the highest number of seeds in no tillage system is related to the highest number of weed plants in the crops during the vegetation season.

The number of weed species found in our trials was comparatively low, while Barberi and Lo Cascio (2001) found more than 40 weed species in the soil seed bank. The differences could be explained by different crop management - conventional in our study and organic in the aforementioned authors' study. A common observation in the studies done in different countries was that weed species diversity increased when arable farming had been changed from conventional to organic management (Albrecht, 2005; Rial-Lovera et al., 2016). On the other hand, the use of herbicides led to a decrease of diversity - in our study the number of weed species decreased from 16 to 12 . The composition of weed seed

Table 3. Weed species composition (\%) in the weed seed bank in 0-10 cm soil layer after five years (in 2012)

\begin{tabular}{|c|c|c|c|}
\hline \multirow{2}{*}{ Weed species } & \multicolumn{3}{|c|}{ Tillage system } \\
\hline & $\mathrm{CT}$ & MT & NT \\
\hline Chenopodium album L. & 33.3 & 18.0 & 19.5 \\
\hline Sinapis arvensis L. & 28.6 & 0.0 & 7.3 \\
\hline Galium aparine $\mathrm{L}$. & 7.1 & 4.0 & 0.0 \\
\hline Viola arvensis Murray & 7.1 & 10.0 & 12.2 \\
\hline Lamium purpureum L. & 2.4 & 22.0 & 7.3 \\
\hline Echinochloa crus-galli (L.) P. Beauv. & 7.1 & 22.0 & 12.2 \\
\hline Tripleurospermum inodorum (L.) Sch. Bip. & 11.9 & 10.0 & 34.1 \\
\hline Thlaspi arvense L. & 0.0 & 8.0 & 0.0 \\
\hline Fallopia convolvulus (L.) À. Löve & 0.0 & 2.0 & 0.0 \\
\hline Stellaria media (L.) Vill. & 0.0 & 0.0 & 2.4 \\
\hline Other & 2.4 & 4.0 & 4.9 \\
\hline
\end{tabular}

CT - conventional tillage 20-22 cm depth, MT - minimum tillage 10-12 cm depth, NT - no tillage

bank was similar to that reported by other authors - more than $90 \%$ of species were broadleaf weeds (Skuodienè et al., 2013, Ali et al., 2017).

Weed communities are influenced by many factors including cropping systems and tillage practices (Kelton et al., 2011). Weed mass was examined twice in winter crops, in 2011 in winter wheat and in 2012 in winter oilseed rape at mid-summer. Significant differences between the tillage systems and years were recorded (Fig. 4).

The two-way analysis of variance (ANOVA) showed that the highest weed mass $(P>0.01)$ was

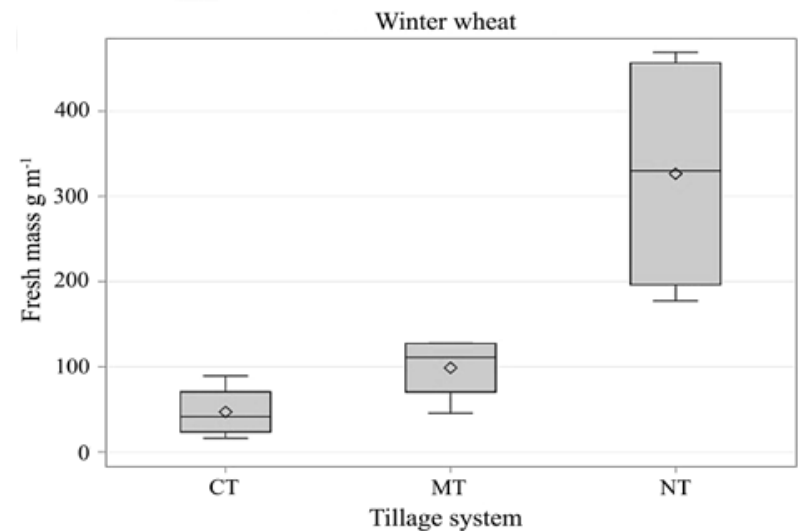

recorded in no tillage system, whereas the lowest $(P>0.01)$ in conventional system. A higher weed mass was recorded in winter oilseed rape crop. This could be explained not only by the influence of meteorological conditions, but also growing technology and different competitiveness of crops.

According to the averaged data, Capsella bursa-pastoris was more prevalent in both years and accounted for more than $50 \%$ of the total weed number. Frequent weeds in winter wheat and winter oilseed rape crop were T. inodorum, Viola arvensis and other annual dicotyledonous weeds (Fig. 5).

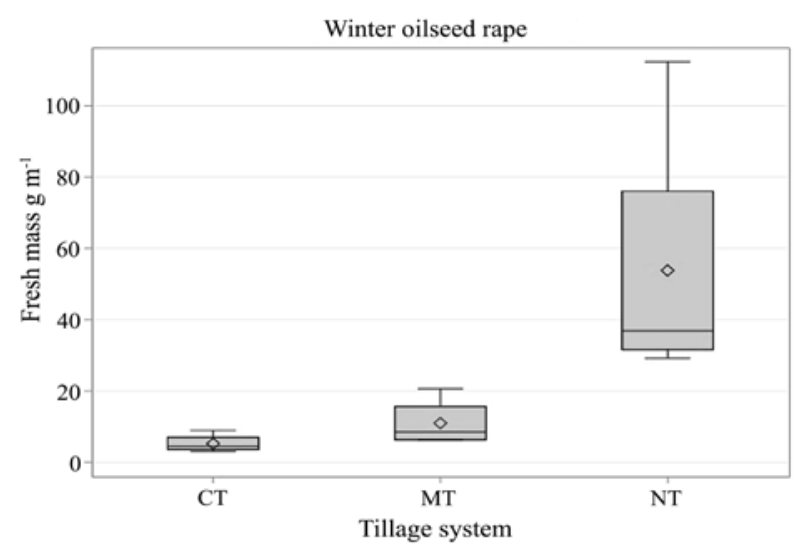

Figure 4. Weed fresh mass in different soil tillage systems in winter wheat (2011) and winter oilseed rape (2012) crops 

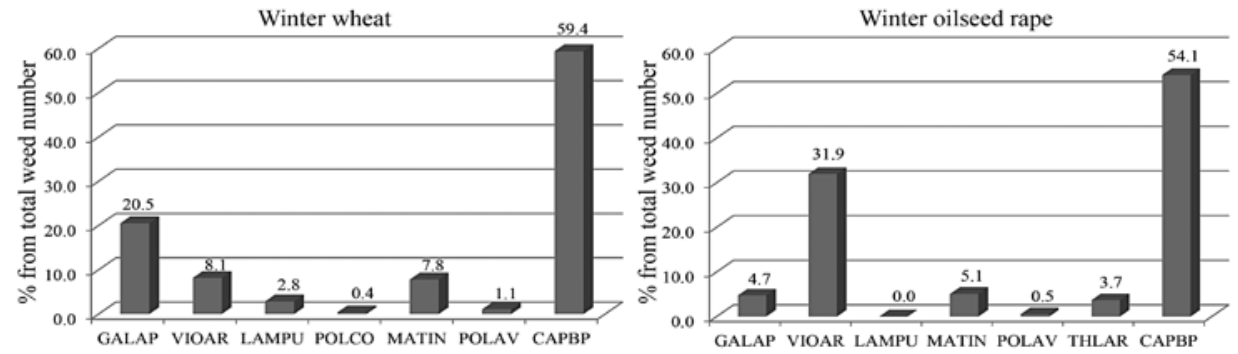

Explanations of ackronyms under Figures 2 and 3

Figure 5. Weed species composition in winter wheat (2011) and winter oilseed rape (2012) crops

Especially high number and mass of $C$. bursapastoris were recorded in the no tillage plots, where it composed more than $70 \%$, whereas $V$. arvensis was more frequent in conventional tillage plots. Other researchers (Steckel et al., 2007) have documented different responses by individual species under varying tillage practices and over time.

\section{Conclusions}

1. Soil weed seed bank varied in density in response to the tillage system applied. The number of weed seeds in the soil was significantly higher in less disturbed soil, particularly in the minimum tillage (MT) treatment. No significant differences in the size of weed seed bank between the minimum tillage and no tillage (NT) treatments were found.

2. Over the five-year period, the weed seed bank significantly decreased, the number of weed species in the soil weed seed bank decreased as well.

3. Apparent differences were recorded in the weed species composition of weed flora in different tillage systems: no tillage promoted infestation of some broadleaf weed species, rapidly increasing the total weed biomass, particularly Capsella bursa-pastoris.

4. In the conventional tillage plots, weed mass was significantly lower compared to lower intensity soil tillage systems: minimum tillage and, especially, no tillage, irrespective of the year.

\section{Acknowledgements}

This study has been supported by the long-term research programme "Productivity and Sustainability of Agricultural and Forest Soils" implemented by Lithuanian Research Centre for Agriculture and Forestry.

We gratefully acknowledge former investigator and leader of this long-term experiment Dr. Albinas Auškalnis (1966-2011).

Received 21022018

Accepted 19062018

\section{References}

1. Albrecht H. 2005. Development of arable weed seedbanks during the 6 years after the change from conventional to organic farming. Weed Research, 45 (5): 339-350. https://doi.org/10.1111/j.1365-3180.2005.00472.x

2. Ali S., Tahir M. N., Shah G. A., Khan M. A., Mahmood S. 2017. Dynamic of seed bank and weed flora in rain-fed wheat as affected by different tillage systems. Pakistan Journal of Agricultural Sciences, 54 (4): 907-917. https://doi.org/10.21162/PAKJAS/17.5023

3. Andrade J. F., Satorre E. H., Ermacora C. M., Poggio S. L. 2017. Weed communities respond to changes in the diversity of crop sequence composition and double cropping. Weed Research, 57 (3): 148-158.

https://doi.org/10.1111/wre.12251
4. Auffret A. G., Cousins S. A. O., 2011. Past and present management influences the seed bank and seed rain in a rural landscape mosaic. Journal of Applied Ecology, 48 (5): 1278-1285. https://doi.org/10.1111/j.1365-2664.2011.02019.x

5. Auškalnienè O., Auškalnis A. 2009. The influence of tillage system on diversities of soil weed seed bank. Agronomy Research, 7 (spec iss. 1): 156-161.

6. Bagavathiannan M. V., Norsworthy J. K., 2012. Late-season seed production in arable weed communities: management implications. Weed Science, 60 (3): 325-334. https://doi.org/10.1614/WS-D-11-00222.1

7. Barberi P., Lo Cascio B. 2001. Long-term tillage and crop rotation effects on weed seed bank size and composition. Weed Research, 41 (4): 325-340.

https://doi.org/10.1046/j.1365-3180.2001.00241.x

8. Birthisel S. K., Gallandt E. R., Jabbour R., Drummond F. A. 2015. Habitat and time are more important predictors of weed seed predation than space on a diversified vegetable farm in Maine, USA. Weed Science, 63 (4): 916-927. https://doi.org/10.1614/WS-D-15-00057.1

9. Bottinelli N., Angers D. A., Hallaire A., Michot D., Le Guillouc C., Cluzeau D., Heddadj D., MenasseriAubry S. 2017. Tillage and fertilization practices affect soil aggregate stability in a Humic Cambisol of Northwest France. Soil and Tillage Research, 170: 14-17. https://doi.org/10.1016/j.still.2017.02.008

10. Cardina J., Herms C. P., Doohan D. J. 2002. Crop rotation and tillage system effects on weed seed banks. Weed Science, 50 (4): 448-460. https://doi.org/10.1614/00431745(2002)050[0448:CRATSE]2.0.CO;2

11. Farmer J. A., Bradley K. W., Young B. G., Steckel L. E., Johnson W. G., Norsworthy J. K., Davis V. M., Loux M. M., 2017. Influence of tillage method on management of Amaranthus Species in Soybean. Weed Technology, 31: 10-20. https://doi.org/10.1614/WT-D-16-00061.1

12. Feiza V., Feiziene D., Kadziene G., Lazauskas S., Deveikyte I., Slepetiene A., Seibutis V. 2011. Soil state in the $11^{\text {th }}$ year of three tillage systems application on a cambisol. Journal of Food, Agriculture and Environment, 9 (3-4): 1088-1095.

13. Feldman S. R., Vesprini J. L., Lewis P. 1994. Survival and establishment of Carduus acanthoides L. Weed Research, 34 (4): 265-273. https://doi.org/10.1111/j.1365-3180.1994.tb01994.x

14. Feldman S. R., Alzugaray C., Torres P. S., Lewis P. 1997. The effect of different tillage systems on the composition of the seedbank. Weed Research, 37 (2): 71-76. https://doi.org/10.1046/j.1365-3180.1996.d01-1.x

15. Gomaa N. 2012. Soil seed bank in different habitats of the Eastern Desert of Egypt. Saudi Journal of Biological Sciences, 19 (2): 211-220. https://doi.org/10.1016/j.sjbs.2012.01.002

16. Gulshan A. B., Dasti A. A., Machmood S., Hussain S., Atta I. 2013. Role of soil seed bank in pattern of species distribution along the aridity gradient by using the technique of multivariate analysis. ARPN Journal of Agricultural and Biological Science, 8: 13-23.

17. Hossain M. M., Begum M., 2015. Soil weed seed bank: importance and management for sustainable crop production - a review. Journal of the Bangladesh Agricultural University, 13 (2): 221-228. https://doi.org/10.3329/jbau.v13i2.28783 
18. Jastrzębska M., Jastrzębski W. P., Hołdyński C., Kostrzewska M. K. 2013. Weed species diversity in organic and integrated farming systems. Acta Agrobotanica, 66 (3): 113-124. https://doi.org/10.5586/aa.2013.045

19. Juchnevičienè A., Raudonius S., Avižienytė D., Romaneckas K., Bogužas V. 2012. Effect of long-term reduced soil tillage and direct seeding on winter wheat crop. Žemès ūkio mokslai, 19 (3): 139-150 (in Lithuanian).

20. Kelton J. A., Price A. J., van Santen E., Balkcom K. S., Arriaga F. J., Shaw J. N. 2011. Weed seed bank density and composition in a tillage and landscape variability study. Communications in Biometry and Crop Science, 6 (1): 21-30.

21. Lal B., Gautam Priyanka, Raja R., Tripathi R., Shahid M., Mohanty S., Panda B. B., Bhattacharyya P., Nayak A. K 2016. Weed seed bank diversity and community shift in a four-decade-old fertilization experiment in rice-rice system. Ecological Engineering, 86: 135-145. https://doi.org/10.1016/j.ecoleng.2015.10.030

22. Munkholm L.J., Heck R.J., Deen B., Zidar T. 2016. Relationship between soil aggregate strength, shape and porosity for soils under different long-term management. Geoderma, 268: 52-59. https://doi.org/10.1016/j.geoderma.2016.01.005

23. Nichols V., Verhulst N., Cox R., Govaerts B. 2015. Weed dynamics and conservation agriculture principles: a review. Field Crops Research, 183: 56-68. https://doi.org/10.1016/j.fcr.2015.07.012

24. Nugis E., Velykis A., Satkus A. 2016. Estimation of soil structure and physical state in the seedbed under different tillage and environmental conditions. ZemdirbysteAgriculture, 103 (3): 243-250. https://doi.org/10.13080/z-a.2016.103.031

25. Pilipavičius V. 2013. Weed seed rain dynamics and ecological control ability in agrophytocenosis. Price A. J., Kelton J. A. (eds). Herbicides - advances in research. InTech, chapter 4, p. 51-83. https://doi.org/10.5772/55972

26. Rahman A., James T. K., Grbavac N., Mellsop J. 1995. Evaluation of two methods for enumerating the soil weeds seedbank: proceedings of $48^{\text {th }}$ New Zealand Plant Protection Conference, p. 95-75.

27. Rao M. P., Cook B. I., Cook E. R., D’Arrigo R. D., Krusic P. J., Anchukaitis K. J., LeGrande A. N., Buckley B. M. Davi N. K., Leland C., Griffin K. L. 2017. European and
Mediterranean hydroclimate responses to tropical volcanic forcing over the last millennium. Geophysical Research Letters, 44 (10): 5104-5112. https://doi.org/10.1002/2017GL073057

28. Raudonius S., 2017. Application of statistics in plant and crop research: important issues. Zemdirbyste-Agriculture, 104 (4): 377-382. https://doi.org/10.13080/z-a.2017.104.048

29. Rial-Lovera K., Davies W. P., Cannon N. D., Conway J. S. 2016. Weed development in spring wheat after contrasting soil tillage and nitrogen management. Annals of Applied Biology, 169 (2): 1-12. https://doi.org/10.1111/aab.12294

30. Sjursen H., Brandsæter L. O., Seljåsen R. 2008. Change in the weed seed bank during the first four years of a five course crop rotation with organically grown vegetables. $16^{\text {th }}$ IFOAM Organic World Congress. Modena, Italy, p. 4 $<$ http://orgprints.org/12251/1/Microsoft_Word_-_Sjursen M08 12251 rev.pdf $>$

31. Skuodienė R., Karčiauskienė D., Čiuberkis S., Repšienė R., Ambrazaitiene D. 2013. The influence of primary soil tillage on soil weed seed bank and weed incidence in a cereal-grass crop rotation. Zemdirbyste-Agriculture, 100 (1): 25-32. https://doi.org/10.13080/z-a.2013.100.004

32. Steckel L. E., Sprague C. L., Stoller E. W. Wax L. M., Simmons F. W. 2007. Tillage, cropping system, and soil depth effects on common waterhemp (Amaranthus rudis) seed-bank persistence. Weed Science, 55 (3): 235-239. https://doi.org/10.1614/WS-06-198

33. Suproniene S., Mankeviciene A., Kadziene G., Feiziene D., Feiza V., Semaskiene R., Dabkevicius Z. 2011. The effect of different tillage-fertilization practices on the mycoflora of wheat grains. Agricultural and Food Science, 20 (4): 316-326.

34. Vakali C., Zaller J. G., Kope U. 2011. Reduced tillage effects on soil physical properties and growth of cereals and associated weeds under organic farming. Soil and Tillage Research, 111: 133-141. https://doi.org/10.1016/j.still.2010.09.003

35. Velykis A., Satkus A., Masilionyte L. 2014. Effect of tillage, lime sludge and cover crop on soil physical state and growth of spring oilseed rape. Zemdirbyste-Agriculture, 101 (4): 347-354. https://doi.org/10.13080/z-a.2014.101.044

36. WRB. 2014. World reference base for soil resources 2014 . World Soil Resources Report 106. FAO, Rome, p. 187-189.

ISSN 1392-3196 / e-ISSN 2335-8947

Zemdirbyste-Agriculture, vol. 105, No. 3 (2018), p. 221-226

DOI 10.13080/z-a.2018.105.028

\title{
Piktžolių sẻklų banko ir floros pokyčiai priklausomai nuo žemès dirbimo
}

\author{
O. Auškalnienė, G. Kadžienė, D. Janušauskaite, S. Supronienė
}

Lietuvos agrarinių ir miškų mokslų centro Žemdirbystès institutas

\section{Santrauka}

Žemès dirbimas ne tik keičia dirvožemio savybes, bet ir yra piktžolių kontrolès priemonè. 2003-2012 m. Lietuvos agrarinių ir miškų mokslų centro Žemdirbystès institute buvo vykdytas stacionarus lauko eksperimentas, kuriame tirti ịvairūs žemès dirbimo būdai: 1) klasikinis intensyvus dirbimas (skutimas 10-12 cm gyliu + arimas 22-24 cm gyliu): prieš sèją dirbta kombinuotu dirvos paruošimo agregatu $4-5 \mathrm{~cm}$ gyliu ir sèta diskine sėjamaja; 2) seklus neariminis pagrindinis (minimalus) žemès dirbimas 10-12 cm gyliu: prieš sèją dirbta kombinuotu dirvos paruošimo agregatu 4-5 cm gyliu, sèta diskine sejjamaja, po derliaus nuemimo purkšta neatrankinio veikimo herbicidu (v. m. glifosatas); 3) žemè nedirbta - tiesiogine sejja: po derliaus nuėmimo purkšta neatrankinio veikimo herbicidu. Eksperimentas vykdytas javų pagrindu sudarytoje sėjomainos rotacijoje. Dirvožemio ėminiai piktžolių sėklų kiekiui ir pasiskirstymui nustatyti buvo paimti 2007 ir 2012 m. po vasarinių miežių (2007) ir žieminių rapsų (2012) derliaus nuėmimo. Piktžolių žalia masè nuimta 2011 ir 2012 m. žieminių kviečių ir žieminių rapsų pasėlyje intensyvaus augalų augimo metu. Per penkerių metų laikotarpi piktžolių sėklų kiekis dirvožemyje esmingai sumažèjo. Esmingai didžiausias piktžolių sẻklų kiekis buvo tiesioginès sėjos laukeliuose. Piktžolių rūšinè sudètis skyrèsi nevienodai įdirbtuose laukeliuose - tiesioginès sėjos laukeliuose itin išplito trikertė žvagine (Capsella bursa-pastoris (L.) Medik.). Mažiausia piktžolių masė nustatyta taikant intensyvų žemės dirbimą, lyginant su minimalaus dirbimo ir ypač tiesioginès sèjos laukeliais. 